\title{
Emission factor, relative ozone formation potential and relative carcinogenic risk assessment of VOCs emitted from manufacturing industries
}

\author{
Hsi-Hsien Yang ${ }^{1}$, Sunil Kumar Gupta ${ }^{1 *}$ (D) and Narayan Babu Dhital ${ }^{1,2,3}$
}

\begin{abstract}
Manufacturing industries are one of the important emission sectors of anthropogenic volatile organic compounds (VOCs). In this study, VOC emission factors, relative ozone formation potential (ROFP) and relative carcinogenic risk $(\mathrm{RCR})$ were estimated for manufacturing industries $(n=13)$ located in central Taiwan. Emission samples were collected in stainless steel canisters and were analyzed with a system of gas chromatography-mass spectroscopy.

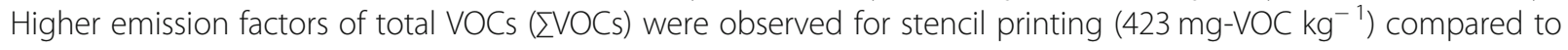
other emission industries. Alkanes constituted the most prominent group of VOCs for steel foundry (42\%), aluminum foundry (25\%) and synthetic resin industries (25\%). Oxygenated VOCs were the most abundant group in the organic solvent (80\%), polyester resin (80\%) and polyurethane (75\%) industries. Moreover, emissions from acrylic resin manufacturing had a major contribution from aromatic compounds (>95\%). Toluene was the topmost compound in terms of its contribution to $\Sigma \mathrm{VOCs}$ in plastic tape manufacturing (44\%), aluminum foundry (40\%), steel foundry (12\%), plastic coating (64\%) and stencil printing (35\%). Analysis of ozone formation potentials showed that the metal product and machinery acrylic resin manufacturing and stencil printing had a higher normalized relative ozone formation potential (ROFP) index and belonged to Level-l emission sources. However, in terms of the relative carcinogenic risk (RCR), integrated iron and steel manufacturing had the highest normalized $R C R$ index that belonged to level-I emission sources. Level-I represents the most important VOC emission sources. This study provides a reactivity- and carcinogenicity-based approach to identify high-priority VOC emission sources. The results of this study would help formulate emission reduction policies and strategies for manufacturing industries.
\end{abstract}

Keywords: Volatile organic compounds, Manufacturing sources, Relative ozone formation potential, Relative carcinogenic risk, Potential source comparison

\section{Introduction}

Manufacturing industries are important stationary emission sources of air pollutants worldwide. These emission sources have become one of the major contributors to air pollution due to a substantial increase in industrial production [1-3]. The pollutants such as particulate

\footnotetext{
* Correspondence: snlenv@gmail.com

'Department of Environmental Engineering and Management, Chaoyang

University of Technology, Taichung 413310, Taiwan

Full list of author information is available at the end of the article
}

matter, oxides of carbon, oxides of nitrogen, polycyclic aromatic hydrocarbons and volatile organic compounds (VOCs) pose threats to human health and the environment [4-7]. VOCs are of interest in part because they participate in atmospheric photochemical reactions that contribute to ozone formation [8]. Tropospheric ozone is formed by chemical reactions involving airborne VOCs, airborne nitrogen oxides, and sunlight [9]. The oxidation products of VOCs may also get absorbed by the atmospheric aerosols [10]. VOCs contain several

(c) The Author(s). 2020 Open Access This article is licensed under a Creative Commons Attribution 4.0 International License, which permits use, sharing, adaptation, distribution and reproduction in any medium or format, as long as you give

appropriate credit to the original author(s) and the source, provide a link to the Creative Commons licence, and indicate if changes were made. The images or other third party material in this article are included in the article's Creative Commons licence, unless indicated otherwise in a credit line to the material. If material is not included in the article's Creative Commons licence and your intended use is not permitted by statutory regulation or exceeds the permitted use, you will need to obtain permission directly from the copyright holder. To view a copy of this licence, visit http://creativecommons.org/licenses/by/4.0/. 
hundreds of species; each species can react with different rates and reaction mechanisms and have different potential for ozone formation [11]. Ozone formation potential (OFP) estimates the contribution of individual VOC species to ozone formation. Developing control strategies for VOC emission sources requires considering not only the emission amount of VOCs but also the chemical reactivity (i.e., maximum incremental reactivity, MIR) of VOC species [12]. The MIR based approach has been recommended by U.S. EPA [13]. Reactivity-based control strategies can be applied to various industrial emission sources to identify the highly reactive VOC emission sources that contribute more to the ozone formation. For example, in Europe, reactivity-based strategies for stationary emission sources resulted in the reduction of tropospheric ozone formation compared to simple massbased strategies [14].

VOC lifespan in the atmosphere could range from a few minutes to several months. So, some of the VOCs may travel over large distances and enter the human body mainly through inhalation or skin absorption causing varieties of health effects [15]. Human health effects can vary among $\mathrm{VOC}$ species, ranging from irritants to cancerous illnesses [16-18]. For example, exposure to BTEX (i.e., benzene, toluene, ethylbenzene and xylene) has been associated with toxicological effects such as depression, respiratory diseases, damage to the circulatory system and cancer [19-22]. Benzene, and 1, 3-butadiene have been identified as carcinogens [23], and wellknown risk factors for various types of cancers [24]. The main carcinogenic risks are associated with the blood (leukemia and non-Hodgkin lymphoma), lung, liver and biliary tract cancer [25-27]. With regard to these risks, the International Agency for Research on Cancer (IARC) has classified benzene as a Group-1 human carcinogen [24]. Moreover, other VOCs such as trichloroethylene and 1,2-dibromoethane are the probable human carcinogens (Group 2A, IARC), ethylbenzene and chloroform are possibly carcinogenic to human (Group 2B, IARC).

Several studies have been conducted on VOC emissions from sources such as road traffic, petrochemical industries, coal burning, biomass burning and solvent use [28-30]. These studies have reported significant differences in the source compositions between different regions. However, studies on VOC emissions from manufacturing industries are still limited [29, 31-33]. The major VOC emission sources include fossil fuel combustion, petrochemical, printing and solvent usage [29, 31, 34, 35]. Wang et al. [35] studied the distribution of VOCs emitted from solvent usage in furniture paint, auto paint and printing ink. Their study indicated that the largest contributing groups among the measured VOCs were aromatics (52\%) followed by alkanes (32\%) and alkenes (16\%). Aromatic compounds such as benzene has been found to be a common byproduct of the chemical manufacturing, petrochemical industries, production of xylene, toluene and other aromatic compounds, industrial solvent and printing sectors [23, 24]. Yuan et al. [29] identified alkanes and aromatic compounds as the most contributing groups in the printing sector. Tsai et al. [36] reported toluene, 1,2,4-trimethyl benzene, $m / p$-xylene, 1-butene, ethylbenzene, and benzene predominantly emitted from an integrated iron and steel plant located in Southern Taiwan.

VOC emissions from the manufacturing industries have a significant impact on air quality and human health. Biological evidence supports the causal link between VOC species and certain cancer. For instance, exposure to benzene and 1,3-butadiene increases the risk of leukemia [21, 37-39]. Toluene causes neurological disorders [40]. Long-term exposure to xylene can cause headaches, tremors and impaired concentration [41]. Occupational epidemiological studies of petrochemical industry workers indicate that benzene may cause lung cancer, multiple myeloma and acute myelogenous leukemia [42, 43]. Increased rates of leukemia risk have been shown in workers of synthetic rubber industries [37].

Stack emissions from different industries might differ greatly in the VOC species compositions. Thus, the emissions from different sources might play roles in atmospheric chemistry and human health hazards in different ways. It is essential to characterize VOC emission sectors, not only in terms of VOC emission concentrations but also in their chemical reactivity and associated health hazards. However, such data are still not sufficient for industrial emission sources. In this study, a few important industrial emission sources were investigated on the basis of emission factors, ROFP and RCR VOCs.

\section{Materials and methods \\ Description of emission sources}

In this study, the following thirteen types of VOC emission sources were selected: organic solvent manufacturing, synthetic resin manufacturing, acrylic resin manufacturing, polyester resin manufacturing, plastic tape manufacturing, aluminum foundry, steel foundry, metal products and machinery industries, integrated iron and steel manufacturing, non-ferrous metal-based manufacturing, polyurethane (PU) leather manufacturing, plastic coating and stencil printing. All of the selected emission sources were located within Taichung city, Taiwan. The sample industries were selected to represent the major industrial emission sources located within Taichung city. The selected emission sources contributed to $73 \%$ of total VOC emissions within the city in the year 2016 [44]. The selected emission sources were grouped into the following five sectors on the basis 
of U.S. EPA's North American Industrial Classification System (NAICS): chemical manufacturing sector (NAIC S 325), plastics products manufacturing sector (NAICS 326), metals manufacturing sector: primary (NAICS 331) and fabricated metal product manufacturing (NAICS 332), leather manufacturing (NAICS 313) and printing and related support activities sector (NAICS 323).

The chemical manufacturing sector incorporates the chemical transformation of organic and inorganic raw materials and the formation of products. In the present study, this sector was represented by the industries that handled organic solvents and various types of resins. The plastic product manufacturing sector incorporated the industry that manufactured adhesive plastic tapes. The metal (primary and fabricated) manufacturing sector included iron and steel industries, metal casting industries, and nonferrous metal industries. In this study, only the sintering process of the integrated iron and steel industry was investigated. The leather/textile manufacturing sector consisted of the facility that handled synthetic leather, spinning natural and manmade fibers into yarns and threads. The printing sector included plastic coating, stencil printing, plate-making and bookbinding.
Detailed information about selected emission sources can be found in Table 1 .

\section{VOCs sampling and analysis}

VOC emissions from manufacturing industries can be categorized into fugitive emissions and stack emissions. The current study was conducted only for stack emissions. Emission samples were collected using $6 \mathrm{~L}$ fused silica stainless steel canisters (Entech Instruments, Cata$\log \# 29-10,622)$ that had been pre-cleaned with high purity-nitrogen and evacuated with an automated canister cleaner. A flow controller and Teflon tubing were used to extract the exhaust gas from emission stacks to the evacuated canisters. The volume of flue gas was measured using a gas flowmeter. The selection of the sampling location in the stack is important to obtain representative samples. To minimize the effects of process variables, monitoring was performed when there was constant flow through stacks. Stack-ports were set by the local environmental protection body for routine monitoring.

The collected samples were analyzed with the Gas Chromatography (7890) Mass Spectroscopy (5977B) system (GC/MS, Agilent Technologies). The details of the

Table 1 Information about emission sectors and sources included in the present study

\begin{tabular}{|c|c|c|c|c|c|}
\hline Number & Sectors & $\begin{array}{l}\text { Emission } \\
\text { sources }\end{array}$ & $\begin{array}{l}\text { No. of } \\
\text { samples }(n= \\
21)\end{array}$ & $\begin{array}{l}\text { Raw } \\
\text { material }\end{array}$ & Activity \\
\hline \multirow[t]{4}{*}{1} & Chemical manufacturing sector (NAICS 325) & Organic solvent & $n=4$ & Solvent & Organic solvent \\
\hline & & Synthetic resin & $n=2$ & $\begin{array}{l}\text { Plastic } \\
\text { pellets, resin }\end{array}$ & Plastic, chemical \\
\hline & & Acrylic resin & $n=2$ & $\begin{array}{l}\text { Acrylic } \\
\text { polymer } \\
\text { resin }\end{array}$ & Acrylic resin \\
\hline & & Polyester resin & $n=1$ & $\begin{array}{l}\text { Polyester } \\
\text { resin }\end{array}$ & Plastic product \\
\hline 2 & Plastics products manufacturing sector (NAICS 326) & Plastic tape & $n=1$ & Ethyl acetate & Tape manufacturing \\
\hline \multirow[t]{5}{*}{3} & $\begin{array}{l}\text { Metals manufacturing sector: Primary (NAICS 331) and } \\
\text { fabricated metal product manufacturing NAICS 332) }\end{array}$ & $\begin{array}{l}\text { Integrated iron } \\
\text { and steel }\end{array}$ & $n=1$ & Sinter & Steel \\
\hline & & $\begin{array}{l}\text { Aluminum } \\
\text { foundry }\end{array}$ & $n=3$ & $\begin{array}{l}\text { Aluminum } \\
\text { alloy ingot }\end{array}$ & $\begin{array}{l}\text { Mechanical equipment, } \\
\text { locomotive parts }\end{array}$ \\
\hline & & Steel foundry & $n=2$ & $\begin{array}{l}\text { Stainless } \\
\text { steel ingot }\end{array}$ & Metal product \\
\hline & & $\begin{array}{l}\text { Metal products } \\
\text { and machinery }\end{array}$ & $n=1$ & $\begin{array}{l}\text { Metal- } \\
\text { hardware } \\
\text { parts }\end{array}$ & Metal product \\
\hline & & $\begin{array}{l}\text { Non-ferrous } \\
\text { metal }\end{array}$ & $n=1$ & - & Mechanical equipment \\
\hline 4 & Leather manufacturing sector (NAICS 313) & PU leather & $n=1$ & $\begin{array}{l}\text { Aqueous } \\
\text { solvent resin }\end{array}$ & Artificial leather \\
\hline \multirow[t]{2}{*}{5} & Printing and related support activities sector (NAICS 323) & Plastic coating & $n=1$ & $\begin{array}{l}\text { Polyester foil } \\
\text { film }\end{array}$ & Plastic coating \\
\hline & & Stencil printing & $n=1$ & Ink & $\begin{array}{l}\text { Printing and data storage } \\
\text { media production }\end{array}$ \\
\hline
\end{tabular}


GC/MS analysis is described elsewhere [45]. The internal calibration method was applied for the quantification of the VOCs. The standard mixture of gases (A715.15B) from Taiwan National Institute for Environmental Analysis was used as the external standard. Bromochloromethane, 1,4-difluorobenzene, chlorobenzene-d5 and 4bromofluorobenzene were used as internal standards. A total of 72 VOC species were quantified in this study. Based on the functional groups, these VOCs were classified as alkanes (24 species), alkenes (8 species), aromatics (18 species), oxygenated VOCs (8 species), halocarbons (13 species) and others (1 $\begin{array}{ll}1 & \text { species })\end{array}$ (Table 2).

Emission factors of the detected VOC species were calculated for each of the emission sources by using Eq. (1).

$$
\text { Emission factor }=\frac{\text { VOC con } . \times \text { Exhaust volume }(\text { dry basis })}{\text { Raw material unit } \times \text { Sampling duration }}
$$

The calculated emission factor of each VOC species was normalized $\left(x_{i, j}\right)$ to the $\Sigma \mathrm{VOCs}$ emission factors in the source sample for each emission source. The detailed concentrations and emission factors can be found in Additional file 1 (Table S1 and Table S2 of Supplemental Materials).

\section{Quality assurance and quality control (QA/QC)}

The canisters were pre-cleaned before sampling with ultra-pure nitrogen (99.999\%) to remove water vapor and contaminants. Canisters were cleaned for 12 cycles of filling and evacuation using a canister cleaning system (3100A, Entech). Replicates were performed for each sample to minimize analytical errors. The blank analysis was run before each sample analysis.

\section{ROFP}

The absolute OFP of VOC species is usually calculated by multiplying its concentration by its MIR value [46, 47]. However, it is usually the relative importance of each VOC species in comparison with the other emission sources that is of more practical significance. Knowing the relative importance of different VOCs allows for targeting more reactive VOCs sources, hence more efficient and flexible for sources comparing strategies. Therefore, ROFP was calculated on the basis of the VOC emission factor (normalized to 1) and the MIR value of each VOC (Eq. (2)).

$$
\operatorname{ROFP}_{j}=\sum_{j=1}^{n} x_{i, j} \times M I R_{i}
$$

where, $R O F P_{j}$ is for source $j\left(\mathrm{~g}-\mathrm{O}_{3} \mathrm{~g} \mathrm{VOCs}^{-1}\right), x_{i, j}$ is the

\begin{tabular}{|c|c|c|c|c|c|c|c|}
\hline No. & Species & No. & Species & No. & Species & No. & Species \\
\hline & Alkanes $(n=24)$ & 20 & n-Octane & 38 & Styrene & 57 & Methyl methacrylate \\
\hline 1 & Isobutane & 21 & n-Nonane & 39 & o-Xylene & 58 & Methyl Isobutyl Ketone \\
\hline 2 & n-Butane & 22 & n- Decane & 40 & Isopropyl benzene & & Halocarbons $(n=13)$ \\
\hline 3 & Isopentane & 23 & n-Undecane & 41 & n-Propyl benzene & 59 & Methylene chloride \\
\hline 4 & 2,2-Dimethylbutane & 24 & n-Dodecane & 42 & m-Ethyl toluene & 60 & Chloroform \\
\hline 5 & 2,3-Dimethylbutane & & Alkenes $(n=8)$ & 43 & p-Ethyl toluene & 61 & Tetrahydrofuran \\
\hline 6 & 2-Methylpentane & 25 & Propene & 44 & 1,3,5-Trimethylbenzene & 62 & 1,2-Dichloroethane \\
\hline 7 & 3-Methylpentane & 26 & 1-Butene & 45 & o-Ethyl toluene & 63 & Trichloroethylene \\
\hline 8 & n-Hexane & 27 & 1,3-Butadiene & 46 & 1,2,4-Trimethylbenzene & 64 & 1,2-Dichloropropane \\
\hline 9 & 2,4-Dimethylpentane & 28 & Cis-2-butene & 47 & 1,2,3-Trimethylbenzene & 65 & Tetrachloroethylene \\
\hline 10 & Methylcyclopentane & 29 & 1-Pentene & 48 & m-Diethyl benzene & 66 & Chlorobenzene \\
\hline 11 & 2-Methylhexane & 30 & Trans-2-pentene & 49 & p-Diethyl benzene & 67 & Bromoform \\
\hline 12 & Cyclohexane & 31 & Isoprene & 50 & Naphthalene & 68 & 1,1,2,2-Tetrachloroethane \\
\hline 13 & 2,3-Dimethylpentane & 32 & 1-Hexene & & Oxygenated VOCs $(n=8)$ & 69 & 1,3-Dichlorobenzene \\
\hline 14 & 3-Methylhexane & & Aromatics $(n=18)$ & 51 & Ethanol & 70 & 1,4-Dichlorobenzene \\
\hline 15 & n-Heptane & 33 & Benzene & 52 & Acrolein & 71 & 1,2-Dichlorobenzene \\
\hline 16 & Methylcyclohexane & 34 & Toluene & 53 & Acetone & & Others (1) \\
\hline 17 & 2,3,4-Trimethylpentane & 35 & Ethylbenzene & 54 & Isopropyl alcohol & 72 & Carbon disulfide \\
\hline 18 & 2-Methylheptane & 36 & m-Xylene & 55 & Methyl Ethyl Ketone & & \\
\hline 19 & 3-Methylheptane & 37 & p-Xylene & 56 & Ethyl acetate & & \\
\hline
\end{tabular}

Table 2 List of the target VOC species 
ratio of EF of VOC species $i$ to $\Sigma \mathrm{VOCs}$ for source $j$, and $M I R_{i}$ is the value of species $i$ as proposed by Carter [11].

\section{RCR}

The absolute carcinogenic risk is usually estimated by multiplying the actual VOC concentration and its carcinogenic risk factor [48]. However, to ensure comparability among different emission sources, carcinogenicity was calculated for each emission source on a relative basis (Eq. (3)).

$$
R C R_{j}=\sum_{i=1}^{n} x_{i, j} \times U R_{i} \times f_{i}
$$

where, $R C R_{j}$ is the source $j \mathrm{mg}^{-1} \mathrm{~m}^{3}, x_{i, j}$ is the ratio of emission factor of VOC species $i$ to $\sum$ VOCs for source $j$, $U R_{i}$ is the carcinogenic risk factor for VOC species $i(\mu \mathrm{g}$ $\left.\mathrm{m}^{-3}\right)^{-1}$, and $f_{i}$ is the unit conversion factor. The U.S. EPA developed Integrated Risk Information System to provide carcinogenic risk factors for VOCs (Additional file 1: Table S3).

\section{Normalized ROFP and RCR}

After obtaining the ROFP and RCR values for different emission sources, they were sorted from high to low.
The normalized ROFP (NROFP) index and normalized RCR (NRCR) index were calculated using the Eqs. (4) and (5).

$$
\begin{aligned}
& N R O F P_{j}=\frac{R O F P_{j}-R O F P_{\text {min }}}{R O F P_{\text {max }}-R O F P_{\text {min }}} \\
& N R C R_{j}=\frac{R C R_{j}-R C R_{\text {min }}}{R C R_{\text {max }}-R C R_{\text {min }}}
\end{aligned}
$$

where, $N R O F P_{j}$ is the normalized ROFP index of source $j, R O F P_{\text {min }}$ is the minimum $R O F P_{j}$ among VOC sources, $R O F P_{\text {max }}$ is the maximum $R O F P_{j}$ among VOC sources, $N R C R_{j}$ is the normalized RCR index of sources $j . R C R_{\text {min }}$ is the minimum $R C R_{j}$ among VOC sources, $R C R_{\max }$ is the maximum $R C R_{j}$ among VOC sources.

\section{Results and discussion}

\section{Emission factors}

The $\Sigma$ VOCs emission factors of the manufacturing sectors are shown in Fig. 1. The sequence of $\Sigma \mathrm{VOC}$ emission factors for the five groups of manufacturing sectors was printing $>$ plastic $>$ metal $>$ chemical $>$ leather. The $\Sigma$ VOCs emission factors of manufacturing sectors were observed to be ranging from 0.00267 to $423 \mathrm{mg}$-VOC $\mathrm{kg}^{-1}$. Among all sectors, the maximum emission factors

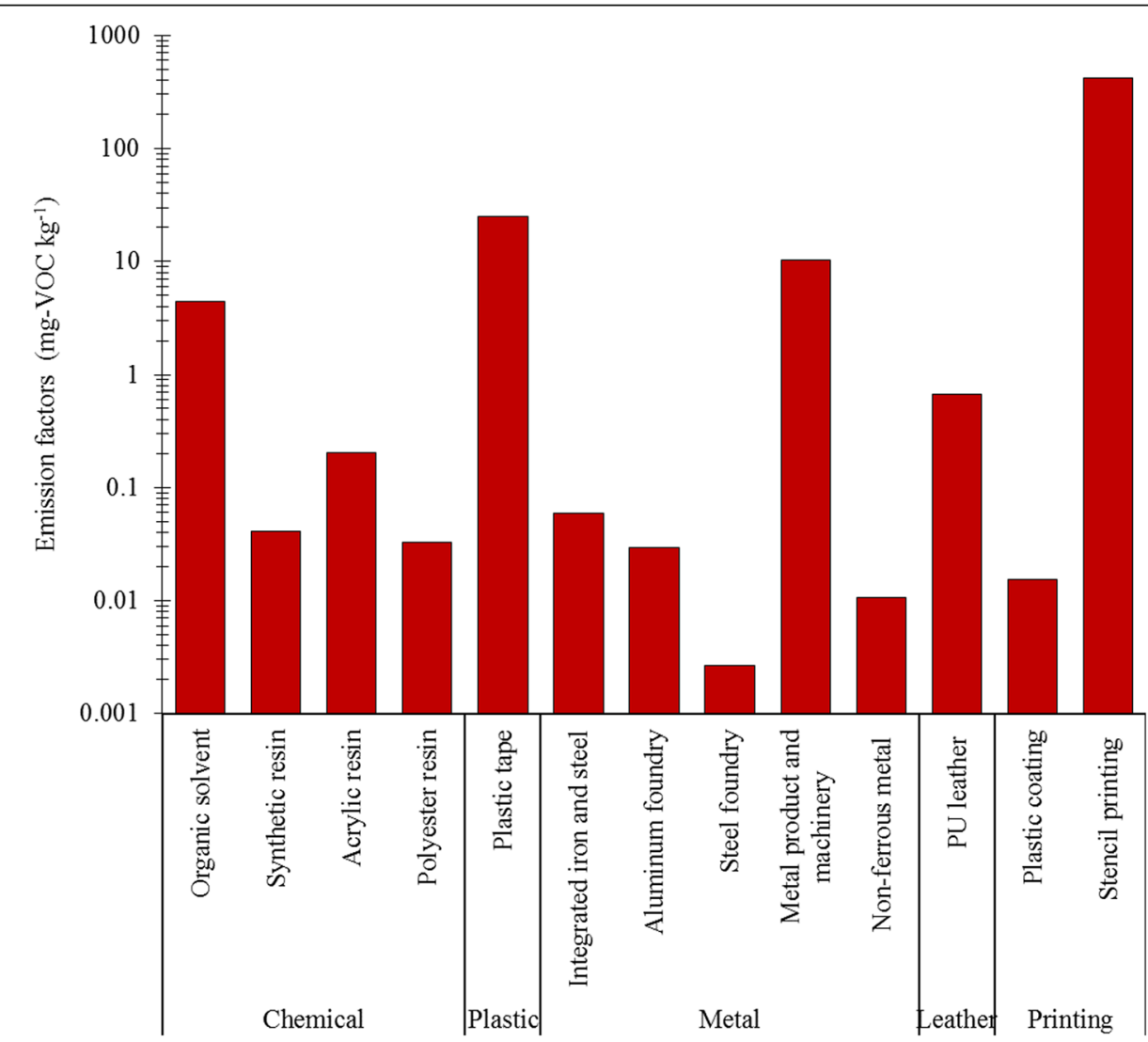

Fig. $1 \Sigma$ VOCs emission factors (plotted on logarithmic scale) for different emission sources 
of $\Sigma \mathrm{VOC}$ were observed for stencil printing (423 mgVOC $\mathrm{kg}^{-1}$ ) followed by plastic tape $(24.9 \mathrm{mg}$-VOC $\mathrm{kg}^{-1}$ ), metal product and machinery (10.3 mg-VOC $\left.\mathrm{kg}^{-1}\right)$ and organic solvent (4.4 $\left.\mathrm{mg}-\mathrm{VOC} \mathrm{kg}^{-1}\right)$. For synthetic resin, acrylic resin, polyester resin, integrated iron and steel, aluminum foundry, steel foundry, non-ferrous metal, and polyurethane (PU) leather and plastic coating, $\Sigma$ VOCs emission factors were found $\leq 1 \mathrm{mg}$-VOC $\mathrm{kg}^{-1}$. Stencil printing had the highest emission factor which could be due to the presence of a large number of organic compounds in printing inks. Toluene was the most abundant VOC species measured in emissions from a Chinese printing industry [49]. In general, toluene, ethylbenzene, xylenes and ethyl acetate were common components in ink solvents [34, 49]. Some other organic compounds such as acetate, glycolic acid butyl ester, butyl glycol were also used in printing inks [50], but their percentage varied largely due to the heavy use of various solvent-based inks and paint solvents. Printing inks are made up of pigments, dyes, additives and carrier solvents. Different types of printing sectors have variable ink flow properties, which range from extremely thin watery through highly viscous to dry powder.

\section{VOC species compositions}

The VOC emission factors have been expressed as the percentage of each species relative to $\Sigma$ VOCs emission factors. The identified VOCs were classified into the following five categories: alkanes, alkenes, aromatics, halocarbons and oxygenated VOCs. As presented in Fig. 2, alkanes formed the dominant VOC group in steel foundry (42\%), aluminum foundry (25\%) and synthetic resin (25\%). A higher proportion of alkenes were observed for metal products and machinery $(60 \%)$ followed by other emission sectors. Zhao et al. [33] observed a high percentage of alkanes $(26 \%)$ followed by alkynes $(16 \%)$, aromatics $(14 \%)$ and alkenes (11\%) in the emissions from iron and steel sectors. In the integrated iron and steel sector, aromatic compounds were the dominant (84\%) VOC group followed by oxygenated VOC and alkenes. Similar results were reported by Tsai et al. [36] that showed a high contribution (45-70\%) of aromatic compounds from integrated iron and steel industry.

The higher proportion of alkanes and alkenes emissions indicates insufficient oxidation of volatile components released from the fuels [46]. Chemical sectors such as organic solvent and polyester resin

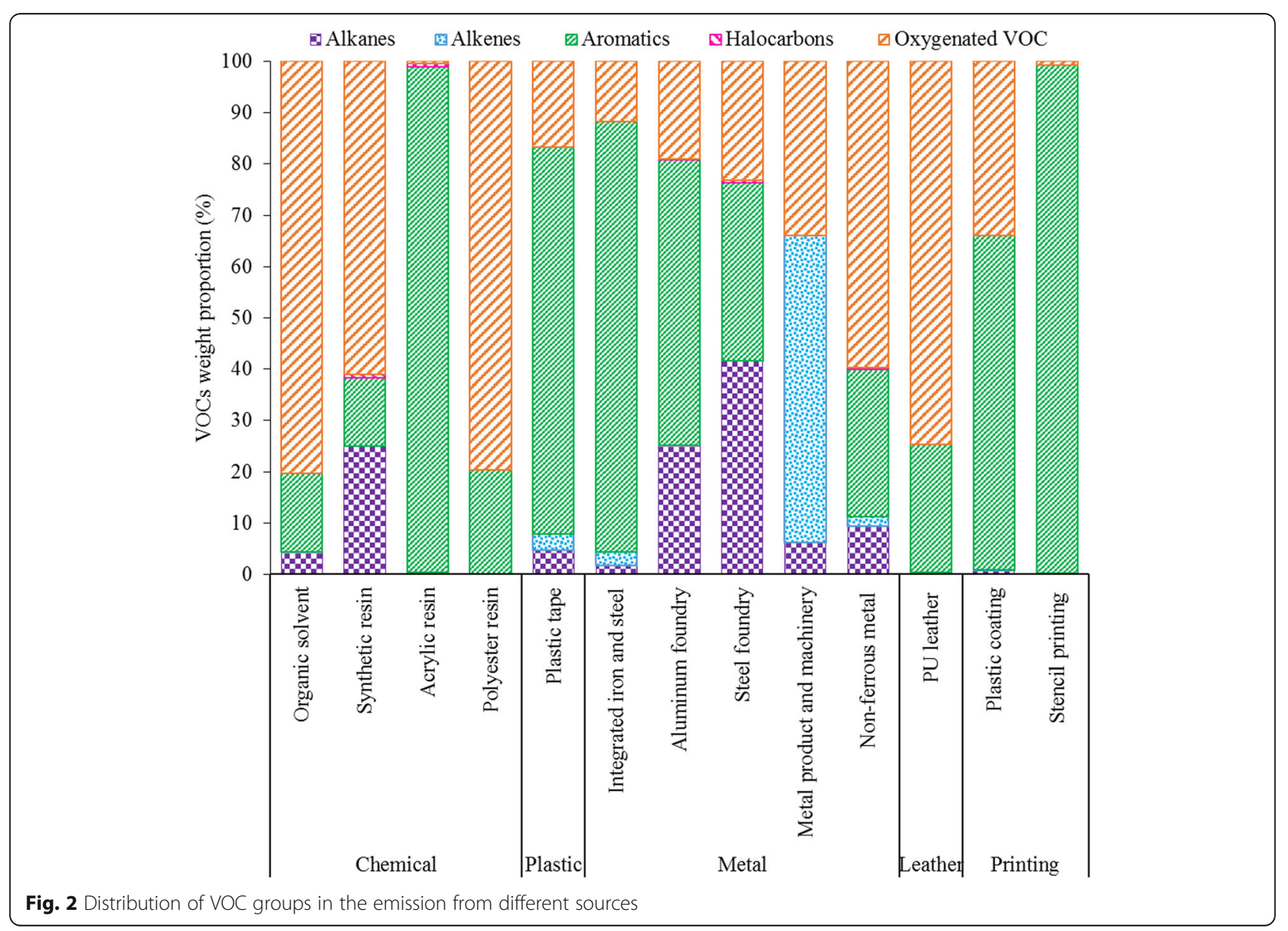


manufacturing were found to have more than $75 \%$ $\Sigma$ VOCs contributed by oxygenated VOCs. Acrylic resin, plastic tape, integrated iron and steel, plastic coating and stencil printing sectors showed the major fraction of $\Sigma$ VOCs contributed by aromatics (65-99\%). Tsai et al. [36] reported the high abundance of aromatic species, including, toluene, 1,2,4 trimethylbenzene, xylene and benzene in the emissions from an integrated iron and steel industry. Yuan et al. [29] reported that the aromatics were the most abundant VOC group in the emissions from solvent usage in auto-painting, architectural painting and printing. The results provide only the functional groups of VOCs for different manufacturing sectors showed the VOCs emission characteristics from different product processes in three plants. Detailed profiles of the VOCs (top 5 contributors) for each manufacturing sector are presented in Table 3 and discussed in the following subsections.

\section{Chemical manufacturing}

The top five VOC species emitted from four chemical manufacturing sectors, such as organic solvent, synthetic resin, polyester resin and acrylic resin industries are shown in Table 3. The VOCs emitted from organic solvent manufacturing were mainly oxygenated VOCs, such as ethyl acetate and acetone, accounting for $>65 \%$ of $\Sigma$ VOCs. Methyl isobutyl ketone, toluene and isopropyl alcohol accounted for a minor fraction of $\Sigma V O C s$. Synthetic and polyester resin manufacturing sectors predominantly emitted oxygenated VOCs like acetone $(56 \%$, $0.023 \mathrm{mg}^{\left.-\mathrm{VOC} \mathrm{kg}^{-1}\right)}$ and ethyl acetate $(80 \%, 0.026 \mathrm{mg}$ VOC $\left.\mathrm{kg}^{-1}\right)$. However, the acrylic resin industry had higher contributions from aromatics (>95\% of $\Sigma \mathrm{VOCs}$ ) such as $m / p / o$-xylene, ethylbenzene, and toluene. Most organic resins are solvent-borne, which contain a mixture of organic solvents, many of which are VOCs. The common solvents used in resins contain toluene, xylene, benzene, ethyl ketone, and methyl isobutyl ketone. Acrylic resin is widely used in paint formulations, and the paints emit predominantly aromatics compounds, such as benzene, toluene, ethylbenzene and xylene [28, 51]. However, the polyester resin was found to have the emission contributions mainly from oxygenated VOCs, as they are formed by the reaction of dibasic organic acids and polyhydric alcohols [52]. The difference in VOC emissions was probably related to the raw materials and products originating from the chemical manufacturing sectors.

\section{Plastic tape manufacturing}

The VOC species emitted from the plastic tape manufacturing industry were mainly aromatics such as toluene, ethyl acetate, $m / p$-xylene and ethylbenzene, accounting for $44 \%$ (11 mg-VOC $\left.\mathrm{kg}^{-1}\right), 16 \%$ (4.0 mg-
VOC $\left.\mathrm{kg}^{-1}\right), 10 \%$ (2.5 mg-VOC kg-1), 10\% (2.5 mg-VOC $\left.\mathrm{kg}^{-1}\right)$ and $5 \%\left(1.3 \mathrm{mg}-\mathrm{VOC} \mathrm{kg}^{-1}\right)$ of $\Sigma \mathrm{VOCs}$ emission factors, respectively. The reason for the high emission of toluene may be related to the nature of raw material used in plastic tape manufacturing. Plastic tape products included petroleum, petroleum by-products, natural rubber, acrylic resins, silicone rubber, dispersions, polymers and solvents. Solvent-based adhesive tape applications require high-stress resistance. There is no solvent-free adhesive tape available that shows equivalent properties. Therefore, there is no alternative to solvent-based adhesives in the high-quality range. All stages of the tape manufacturing process included hot melts releasing VOCs into the atmosphere. Tsubaki et al. [53] found toluene to be the major VOC species emitted from the double-sided pressure-sensitive adhesive tape.

\section{Metal manufacturing}

Toluene, ethyl acetate, acetone, 1-butene, $n$-butane, cis2-butene, benzene, and ethanol were the main VOC species emitted from the metal-based manufacturing industries. Toluene was the most abundant VOC species in the emissions from both aluminum and steel foundries, accounting for $40 \%\left(0.012 \mathrm{mg}-\mathrm{VOC} \mathrm{kg}^{-1}\right)$ and $12 \%$

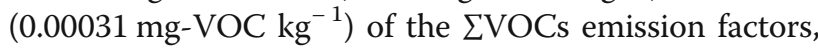
respectively. Benzene had the highest contribution (41\%, $0.024 \mathrm{mg}$-VOC $\mathrm{kg}^{-1}$ ) in the integrated iron and steel sector. Samples from metal product and machinery and non-ferrous metal showed the major fractions of 1butene and ethyl acetate emissions, accounting for $40 \%$ (4.2 $\mathrm{mg}$-VOC $\mathrm{kg}^{-1}$ and $38 \%$ (0.0041 $\mathrm{mg}-\mathrm{VOC} \mathrm{kg}^{-1}$ ) of the $\Sigma$ VOCs emission factors, respectively (Table 3). VOC compositions in the emissions from the integrated iron and steel manufacturing sector were similar to those reported by the previous work [36] for four processes of the integrated iron and steel industries. The study reported benzene, toluene, xylene, $n$-butane and 2methylpentane for the sintering process as the major VOCs. Toluene, 1,2,4-trimethyl benzene, isopentane, $\mathrm{m}$ / p-xylene, 1-butene, ethylbenzene, benzene, trichloroethylene, $n$-hexane and $n$-pentane were the major VOC species in coke making exhausts [36].

\section{Leather manufacturing}

The major VOCs emitted from PU leather industry were methyl ethyl ketone, toluene and methyl methacrylate, accounting for $60 \%\left(0.40 \mathrm{mg}-\mathrm{VOC} \mathrm{kg}^{-1}\right), 24 \%$ (0.16 mgVOC $\mathrm{kg}^{-1}$ ) and $13 \%$ (0.085 mg-VOC kg-1) of $\Sigma$ VOCs, respectively. The contributions of major VOC species detected in this study were similar to those reported in the earlier studies. Chang and Lin [54] obtained a higher amount of toluene and methyl ethyl ketone in emissions from coating, drying and surface treating processes of the PU leather industry. Wang et al. [55] reported a high 


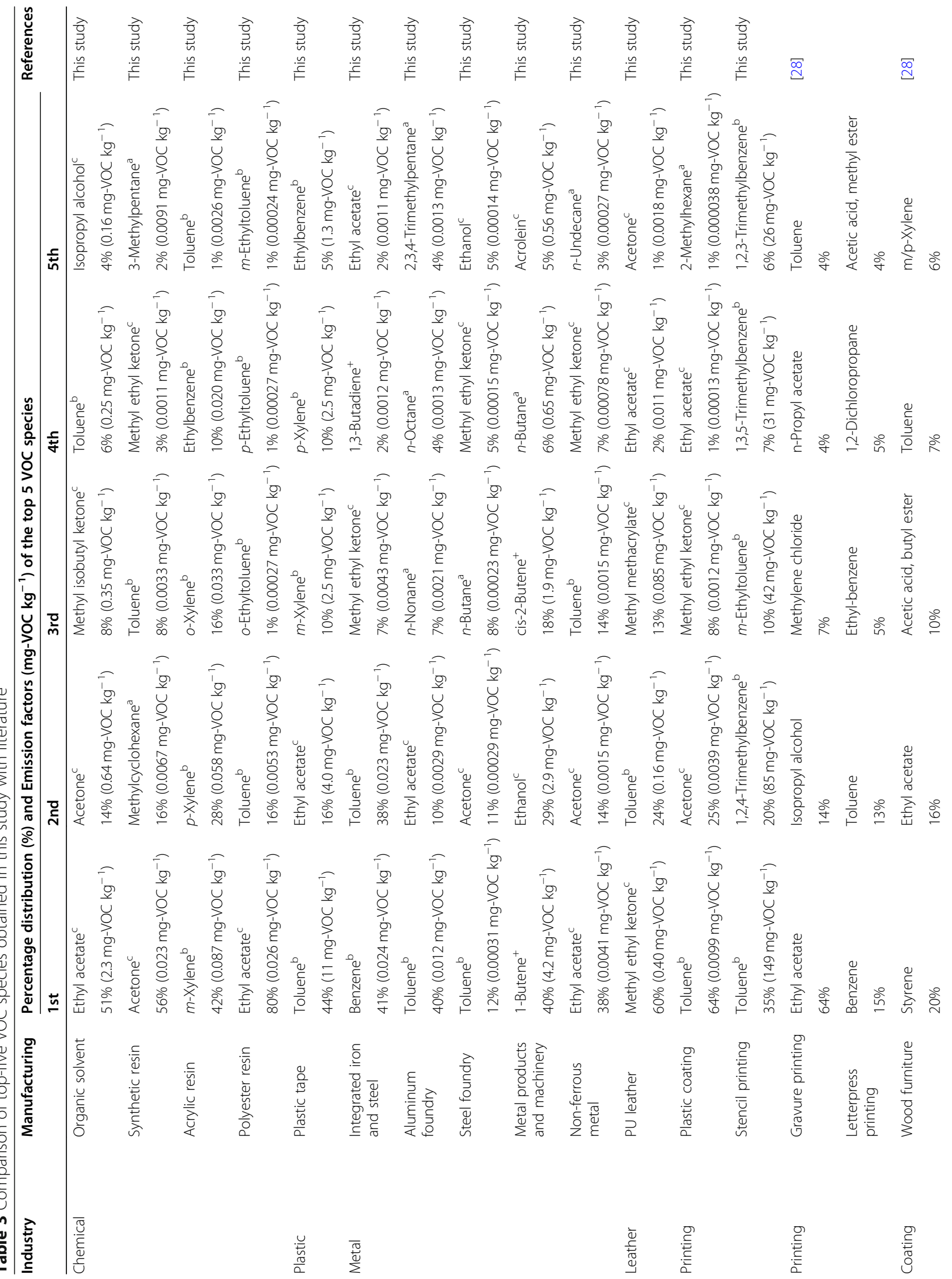




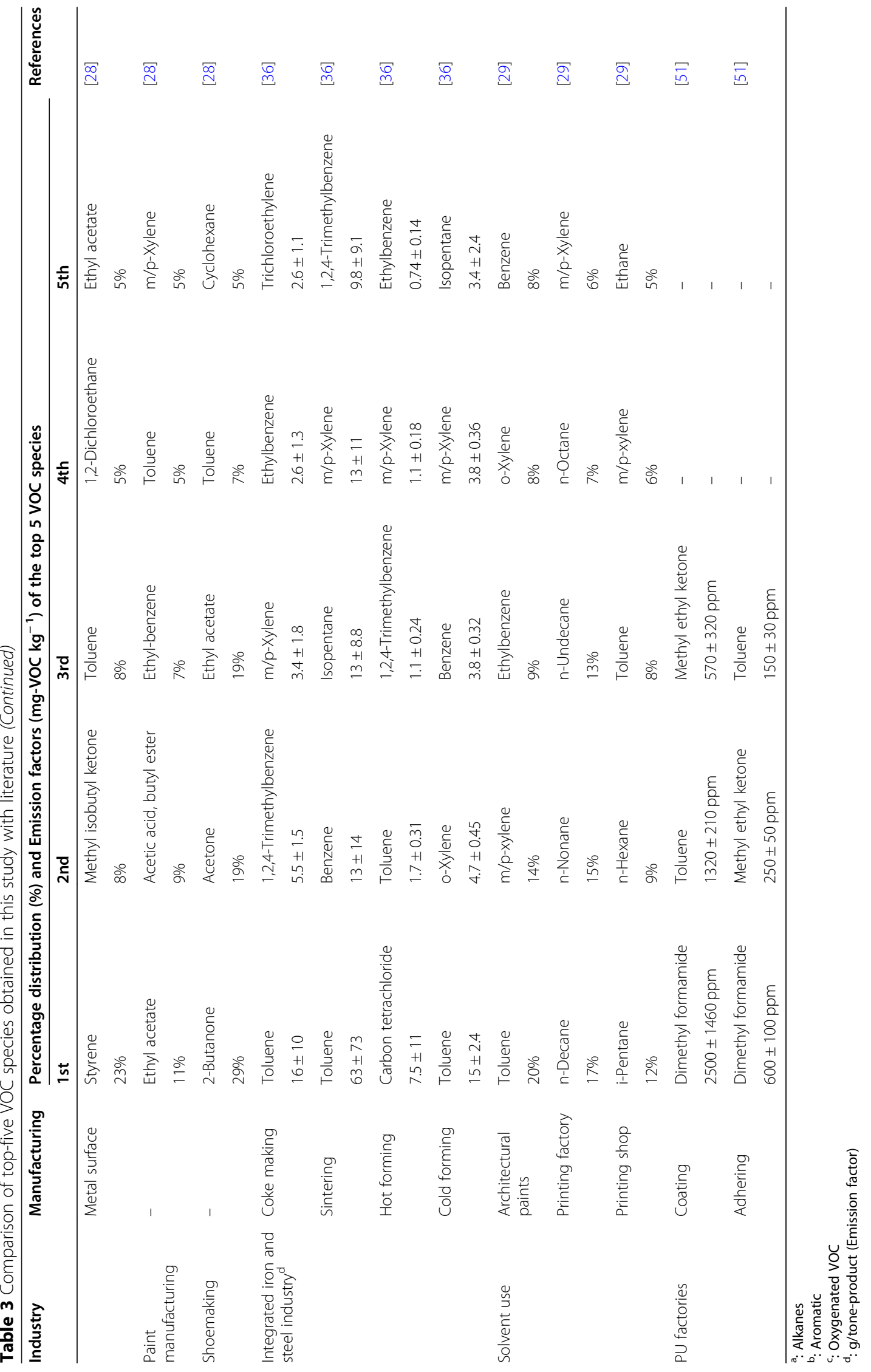



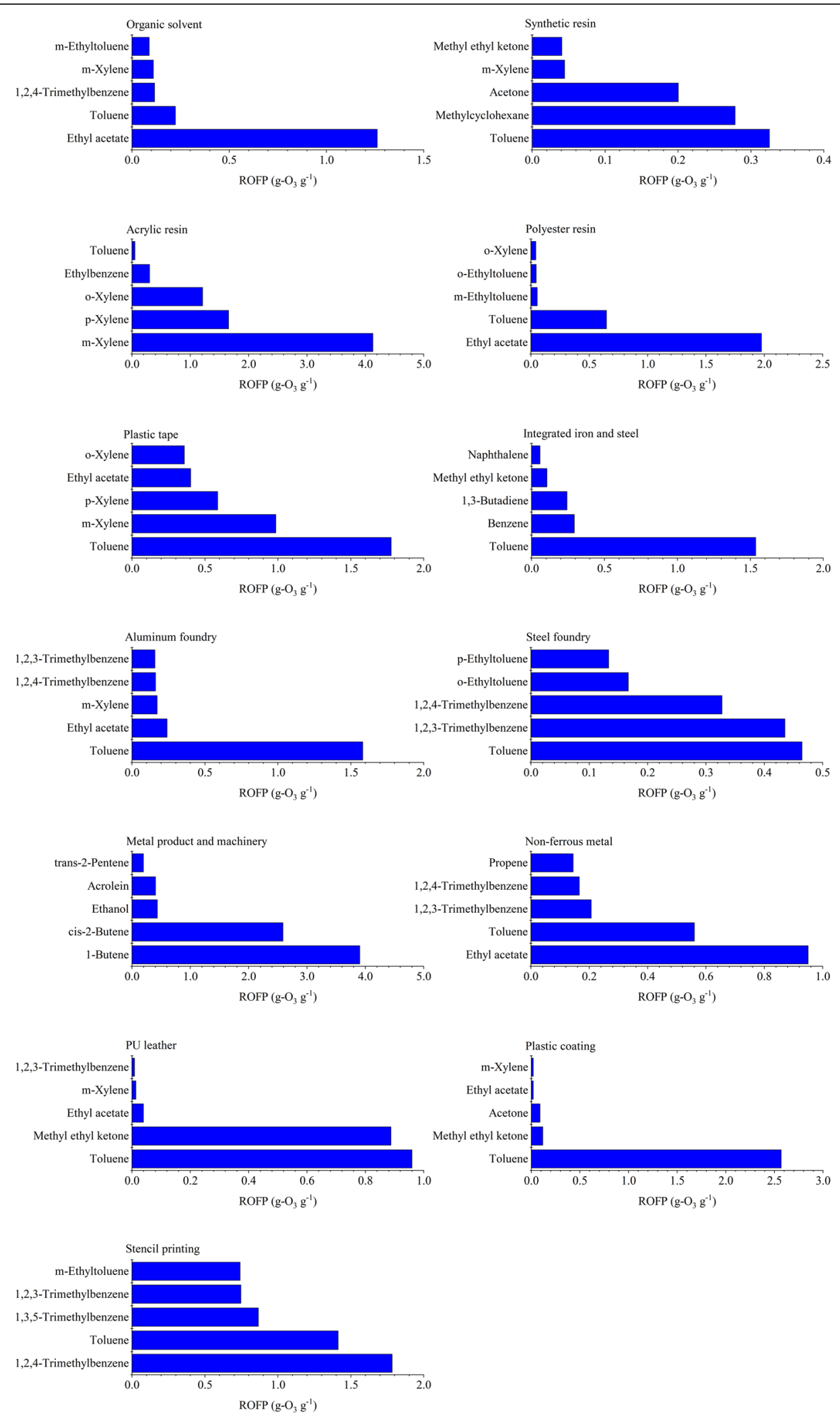

Fig. 3 Top-five VOC species in terms of the contribution to the ozone formation potential for different emission sectors 
quantity of 2-butanone, toluene and ethyl acetate in different areas of the manufacturing facility such as manufacturing department, semi-finished raw material department, resin warehouses and outside vicinity of the industries. Organic solvents are widely used in the PU industries which could be a potential source of VOCs. The species of organic solvents include toluene, methyl ethyl ketone and dimethylformamide. Some solvents are added as thinners and additives to avoid excessive viscosity of polyurea-formaldehyde in PU industry [54]. These results showed that the VOC species compositions were attributable to the organic solvent and other raw materials used in PU industries.

\section{Printing sectors}

The printing sector in the present study included plastic coating and stencil printing (Table 3). Toluene was the most abundant species in the emissions of plastic coating and stencil printing, accounting for $64 \%(0.0099 \mathrm{mg}-$ VOC $\mathrm{kg}^{-1}$ ) and 35\% (149 mg-VOC $\mathrm{kg}^{-1}$ ) of $\Sigma$ VOCs emission factors, respectively. However, methyl methacrylate, ethyl acetate, acetone, methyl ethyl ketone and 2-methyl hexane accounted for a minor fraction of $\Sigma$ VOCs for both sectors. Organic solvents are widely used in plastic coating and ink printing [29] which could make an important source of aromatic compounds. Li et al. [34] obtained a higher percentage of alkanes (45\%) and aromatics $(47 \%)$ in printing ink. The study reported that VOC species emitted from the ink printing sectors were mainly, alkanes and aromatics. Some other studies found that toluene, benzene, and some oxygenated organics are the typical species emitted form printing sectors [28, 34, 56]. Zheng et al. [28] reported aromatics (e.g., benzene and toluene) as the major species of letterpress printing, while ethyl acetate and isopropyl alcohol were important VOCs in offset printing and gravure printing processes. Raw materials and derivatives might be the responsible factor for the observed differences in the emissions from different printing sectors.

\section{ROFP}

The top five VOCs in terms of their contributions to ROFP in different emission sectors are shown in Fig. 3. The top five VOC species for organic solvent included ethyl acetate, toluene, 1,2,4-trimethylbenzene, $m$-xylene and $m$-ethyl toluene that together accounted for $75 \%$ of the total ROFP. In synthetic resin industries, the top five ROFP VOCs accounted for $72 \%$ of the total ROFP. They included aromatics (toluene and $m$-xylene), alkanes (methylcyclohexane), and oxygenated VOCs (acetone and methyl ethyl ketone). In the polyester resin industry, oxygenated and aromatic species were predominant contributors to the total ROFP, whereas in the acrylic resin industry, the aromatic VOCs $\left(\mathrm{m} / \mathrm{p} / \mathrm{o}^{-}\right.$xylene, ethylbenzene and toluene) were the major contributors to ROFP. 1-butene and ethyl acetate were the dominant contributors to the total ROFP for metal product and machinery and non-ferrous metal sectors, respectively. Similarly, toluene was the highest contributor followed by $m / p$-xylene and ethyl acetate in the plastic tape manufacturing sector. Likewise, toluene was the dominant contributor of total ROFP for the aluminum foundry, steel foundry, integrated iron and steel, PU leather and plastic coating sectors. For the stencil printing sector, 1, 2,3-trimethyl benzene was the major contributor to the total ROFP. Moreover, several aromatic VOCs including 1,3,5-trimethyl benzene, 1,2,3-trimethylebenzene and $m$ ethyltoluene were also obtained as the top five VOCs contributing to the total ROFP in the stencil printing sector.

The ROFPs of VOCs varied widely across different emission sectors (Additional file 1: Fig. S1). The total ROFP of metal product and machinery emission was the highest $\left(7.6 \mathrm{~g}-\mathrm{O}_{3} \mathrm{~g} \mathrm{VOCs}^{-1}\right)$ among all emission sources, followed by acrylic resin manufacturing $\left(7.4 \mathrm{~g}-\mathrm{O}_{3} \mathrm{~g}\right.$ $\left.\mathrm{VOCs}^{-1}\right)$, stencil printing $\left(6.5 \mathrm{~g}-\mathrm{O}_{3} \mathrm{~g}-\mathrm{VOCs}^{-1}\right)$, and plastic tape manufacturing $\left(4.6 \mathrm{~g}-\mathrm{O}_{3} \mathrm{~g}-\mathrm{VOCs}^{-1}\right)$. In the metal product and machinery sector, alkenes were the main contributors, accounting for $88 \%$ of total ROFP. However, in acrylic resin manufacturing, printing and plastic tape sectors, aromatics contributed to $99.9,99.8$ and $85 \%$ of total ROFP, respectively. The major aromatic VOCs for these emission sources were 1 -butene, $m$-xylene, 1,2,4-trimethylbenzene and toluene. The total ROFP for synthetic resin manufacturing emissions was the lowest because the oxygenated VOCs with low reactivity accounted for the major fraction of $\Sigma$ VOCs. The ROFP contributions for acrylic resin, plastic tape, metal manufacturing (integrated iron and steel, aluminum and steel foundries) and printing (plastic coating and stencil printing) emissions were mainly from aromatic VOCs. However, oxygenated VOCs were the major contributing group to the ROFP for other manufacturing sectors (i.e., organic solvent, polyester resin, no-ferrous metal and PU leather). Tsai et al. [36] reported toluene, 1-butene, $\mathrm{m} / \mathrm{p}$-xylene, o-xylene, 1,2,4-trimethylbenzene, ethylbenzene, 1,3.5-trimethylbenzene, 1,2, 3 -trimethylbenzene as the major VOCs in terms of OFP in the emissions from four process units of an integrated iron and steel plant. The sequence of OFP for four processes was as follows: cold forming $\approx$ sintering $>$ hot forming > cakemaking. Furthermore, OFP of cold forming and sintering process is about 4 and 5 times higher than that of hot forming and cakemaking processes, respectively. $\mathrm{Ou}$ et al. [57] reported that industrial solvents and gasoline vehicles contributed 33 and 18\% of anthropogenic OFP of VOC emissions, respectively, whereas, motorcycles and industrial processes accounted for 14 and $13 \%$, respectively. Li et al. [34] also reported a similar 
(a)

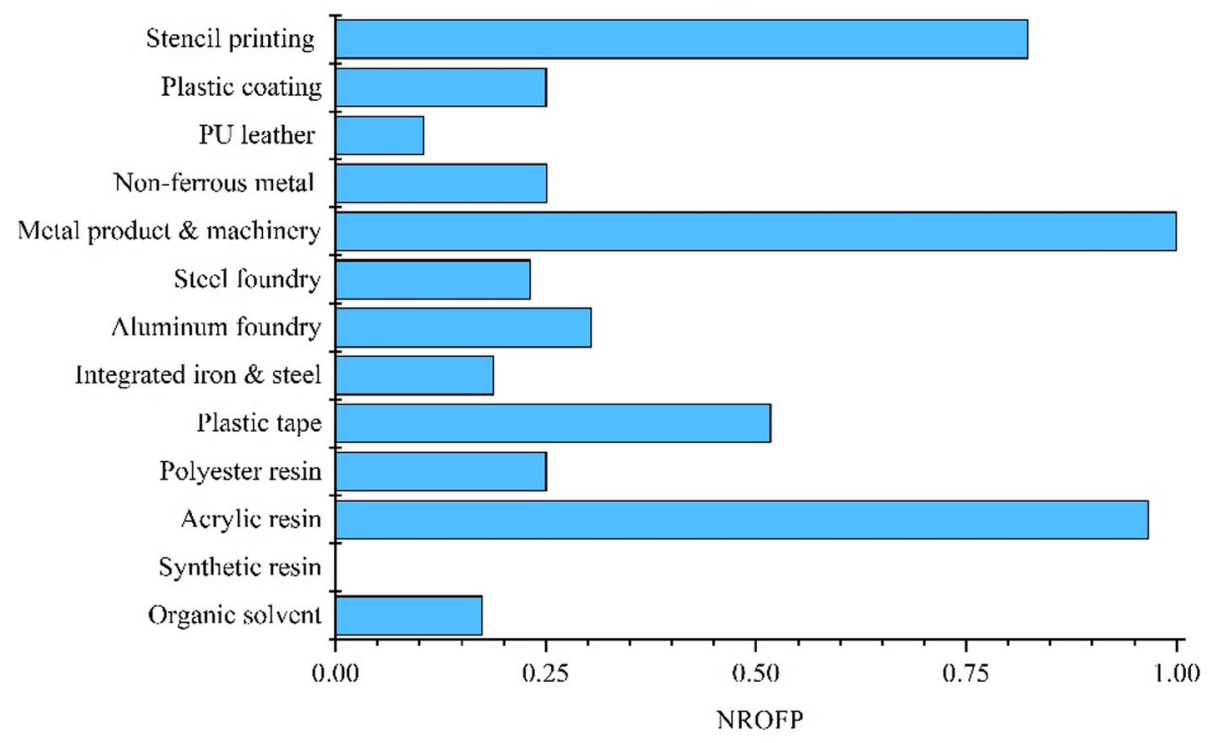

(b)

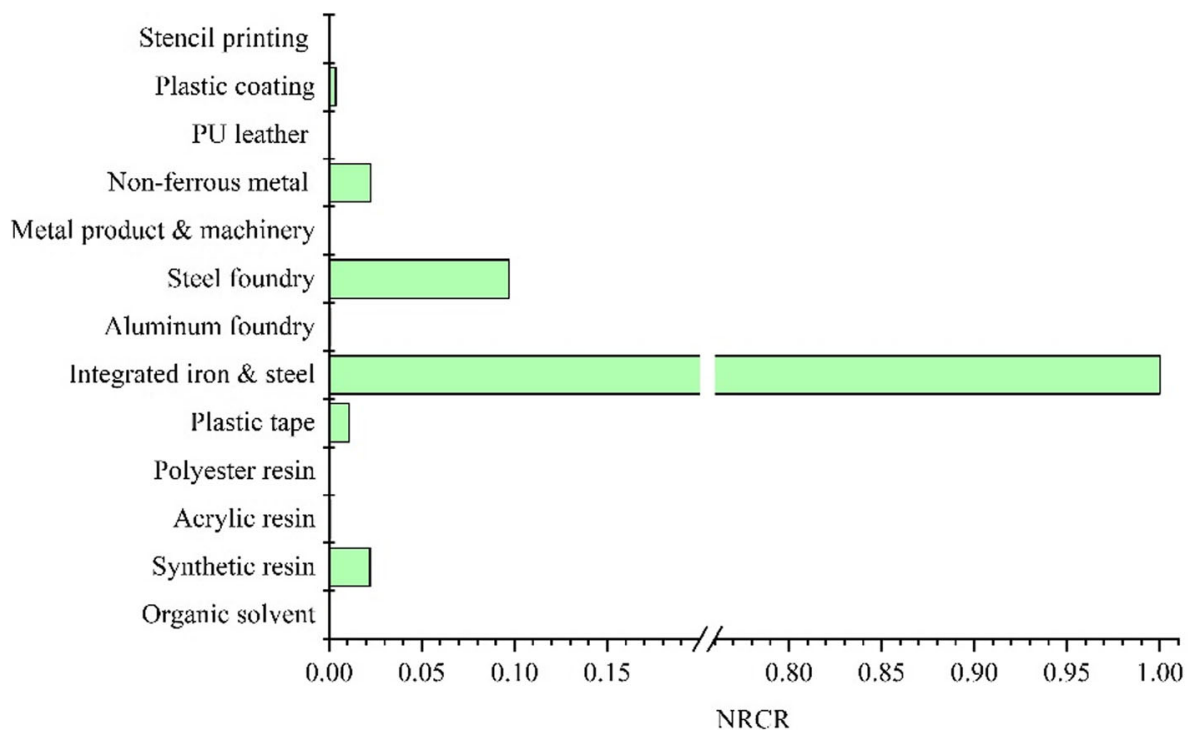

Fig. 4 Comparison of emission sectors based on a NROFP; normalized relative ozone formation potential, and $\mathbf{b}$ NRCR; normalized relative carcinogenic risk

VOC emission pattern for iron and steel and printing sectors. A detailed comparison of the results with literature can be found in the supplementary material (Additional file 1: Table S4). It should be noted that the ozone formation potential depends on the speciated VOC emission concentrations and their MIR values. Thus, VOCs with high emission factors may not always be the major contributors to ozone formation.

\section{RCR}

The RCR of each of the emission sources investigated in this study has been presented in Additional file 1: Fig.
S2. The RCR of emissions from the integrated iron and steel sector was the highest among all tested emission sources with the risk value of $41 \times 10^{-8} \mathrm{mg}^{-1} \mathrm{~m}^{3}$, followed by steel foundry $\left(4.0 \times 10^{-8} \mathrm{mg}^{-1} \mathrm{~m}^{3}\right)$ and nonferrous metal industry $\left(9.2 \times 10^{-9} \mathrm{mg}^{-1} \mathrm{~m}^{3}\right)$. RCR values of other emission sectors such as organic solvent, synthetic resin, acrylic resin, plastic tape, aluminum foundry, PU leather, plastic coating and stencil printing ranged from $1.2 \times 10^{-10}-9.1 \times 10^{-9} \mathrm{mg}^{-1} \mathrm{~m}^{3}$. The RCRs were not calculated for polyester resin and metal product and machinery because of the unavailability of the carcinogenic risk factor values for the VOCs detected in 
the emissions of those sources. The highest relative RCRs were observed for the integrated iron and steel manufacturing sector and steel foundry because those sources emitted a high amount of benzene. Several VOC species, including benzene, chloroform, trichloroethylene, bromoform and 1,3-butadiene are classified as carcinogenic compounds according to the Integrated Risk Information System. Industrial manufacturing sectors are reported as the major VOC emission sources [28, 36]. Several previous studies have assessed cancer risks for inhalation exposure to VOCs in industrial areas, but most of them focus on the ambient VOCs [58-60].

\section{Specific potential emission sources}

A comparison of potential VOC emission sources based on ROFP and RCR between different emission sectors is presented in Fig. 4. NROFP and NRCR were categorized into four levels: Level-I (0.75-1.00), Level-II (0.50-0.75), Level-III (0.25-0.50) and Level-IV (0-0.25) where LevelI represents the most important VOC emission sources and Level-IV represents the least important emission source in terms of NROFP and NRCR. Metal product and machinery, acrylic resin and stencil printing sectors belonged to the Level-I emission sources (NROFP index: $>0.75$ ). However, in terms of the NRCR, it was found that the integrated iron and steel had the highest NRCR index that belonged to Level-I emission sources. Therefore, it can be concluded that not only the single factor such as OFP but also the cancer risk should be taken into consideration for the identification of potentially important VOC emission sources.

\section{Conclusions}

In this study, 13 types of stationary emission sources were investigated for emission factors of speciated VOCs and associated ROFP and RCR. ROFP and RCR were used for the identification of potentially important VOC emission sectors. The results showed that the maximum $\Sigma$ VOCs emission factors were observed for stencil printing (423 mg-VOC kg-1) among all emission sources. Alkanes formed the dominant VOC group in the steel foundry ( $42 \%$ of $\Sigma$ VOCs emission factors), aluminum foundry (25\% of $\Sigma$ VOCs emission factors) and synthetic resin (25\% of $\Sigma$ VOCs emission factors). However, in the chemical sector (synthetic and polyester resin), oxygenated VOCs such as acetone $(56 \%$ of $\Sigma \mathrm{VOCs}$ emission factors) and ethyl acetate ( $80 \%$ of $\Sigma$ VOCs emission factors) were the major contributors to total VOCs. Xylene, ethylbenzene, and toluene formed $>95 \%$ of $\Sigma$ VOCs in the emissions from acrylic resin manufacturing. Analysis of ROFP showed that metal product and machinery sector, acrylic resin manufacturing and stencil printing were potentially important emission sources in terms of OFP. In terms of the NRCR, integrated iron and steel sector was the potentially important source with the highest NRCR index. The results suggested that the reactivityand carcinogenicity-based approach is required for prioritizing the emission sources. Toluene, xylene, 1,2,4-trimethylbenzene and other high OFP-contributing species were the major reactive species that could be targeted while developing control strategies. In addition, carcinogenic VOCs such as benzene, chloroform, trichlorethylene, bromoform and 1, 3-butadiene should also be targeted for emission control.

\section{Supplementary Information}

The online version contains supplementary material available at https://doi. org/10.1186/s42834-020-00068-2.

Additional file $\mathbf{1}$ Table $\mathbf{S 1}$ Average concentrations of the VOC species identified in different manufacturing sectors. Table $\mathbf{S 2}$ Emission factors of the VOC species identified in different manufacturing sectors. Table S3 Carcinogenic inhalation risk factor of VOC species. Table S4

Comparison of ozone formation potential of VOC obtained in this study and with previous studies. Fig. S1 Relative ozone formation potential of VOCs for different emission sources. Fig. S2 Relative carcinogenic risk of VOCs for different emission sources.

\section{Acknowledgements}

The authors would like to thank Yueh-Shu Hsieh and Kuei-Ting Lee for their invaluable help in sampling and laboratory works.

\section{Authors' contributions}

HHY contributed to the study design, data analysis, drafting and editing manuscript. SKG and NBD led sampling, analysis and contributed to the study design, data analysis, drafting and editing manuscript. The authors read and approved the manuscript.

\section{Funding}

This research did not receive any specific grant from funding agencies in the public, commercial, or not-for-profit sectors.

Availability of data and materials

All data generated or analyzed during this study appear in the submitted article.

\section{Competing interests}

The authors declare that they have no competing interests.

\section{Author details}

${ }^{1}$ Department of Environmental Engineering and Management, Chaoyang University of Technology, Taichung 413310, Taiwan. ${ }^{2}$ Department of Applied Chemistry, Chaoyang University of Technology, Taichung 413310, Taiwan. ${ }^{3}$ Department of Environmental Science, Patan Multiple Campus, Tribhuvan University, Lalitpur 44700, Nepal.

Received: 30 May 2020 Accepted: 28 October 2020

Published online: 23 November 2020

\section{References}

1. Hui LR, Liu XG, Tan QW, Feng M, An JL, Qu Y, et al. Characteristics, source apportionment and contribution of VOCs to ozone formation in Wuhan, Central China. Atmos Environ. 2018;192:55-71.

2. Wei YG, Gu J, Wang HW, Yao T, Wu ZZ. Uncovering the culprits of air pollution: evidence from China's economic sectors and regional heterogeneities. J Clean Prod 2018;171:1481-93.

3. Yang HH, Gupta SK, Dhital NB, Wang LC, Elumalai SP. Comparative investigation of coal- and oil-fired boilers based on emission factors, ozone and secondary organic aerosol formation potentials of VOCs. J Environ SciChina 2020;92:245-55. 
4. Deng CX, Jin YJ, Zhang M, Liu XW, Yu ZM. Emission characteristics of VOCs from on-road vehicles in an urban tunnel in eastern China and predictions for 2017-2026. Aerosol Air Qual Res 2018;18:3025-34.

5. Saini J, Dutta M, Marques G. A comprehensive review on indoor air quality monitoring systems for enhanced public health. Sustain Environ Res 2020; 30:6.

6. Tsai JH, Chen SJ, Lin SL, Huang KL, Hsueh CK, Lin CC, et al. Emissions of PM2.5-bound polycyclic aromatic hydrocarbons and metals from a diesel generator fueled with biodiesel converted from used cooking oil. Aerosol Air Qual Res. 2019;19:1555-65.

7. Garcia JA, Vallar E, Galvez MC, Bagtasa G. Application of the WRF/Chem v.3. 6.1 on the reanalysis of criteria pollutants over Metro Manila. Sustain Environ Res 2019:29:38.

8. Tsai $\mathrm{JH}$, Yao YC, Huang PH, Chiang HL. Fuel economy and volatile organic compound exhaust emission for motorcycles with various running mileages. Aerosol Air Qual Res 2018;18:3056-67.

9. Wu WJ, Zhao B, Wang SX, Hao JM. Ozone and secondary organic aerosol formation potential from anthropogenic volatile organic compounds emissions in China. J Environ Sci-China 2017:53:224-37.

10. Tajuelo M, Rodriguez A, Baeza-Romero MT, Aranda A, Diaz-de-Mera Y, Rodriguez D. Secondary organic aerosol formation from a-methylstyrene atmospheric degradation: role of NOx level, relative humidity and inorganic seed aerosol. Atmos Res 2019;230:104631.

11. Carter WP. Updated maximum incremental reactivity scale and hydrocarbon bin reactivities for regulatory applications. 2010. https://ww3.arb.ca.gov/ regact/2009/mir2009/mir10.pdf. Accessed 27 Sep 2020.

12. Avery RJ. Reactivity-based VOC control for solvent products: more efficient ozone reduction strategies. Environ Sci Technol 2006;40:4845-50.

13. USEPA. Revisions to the California State Implementation Plan and Revision to the Definition of Volatile Organic Compounds (VOC)-Removal of VOC Exemptions for California's Aerosol Coating Products Reactivity-based Regulation. Washington, DC: US Environmental Protection Agency; 2005.

14. Derwent RG, Jenkin ME, Passant NR, Pilling MJ. Reactivity-based strategies for photochemical ozone control in Europe. Environ Sci Policy 2007;10:445-53.

15. Montero-Montoya R, Lopez-Vargas R, Arellano-Aguilar O. Volatile organic compounds in air: sources, distribution, exposure and associated illnesses in children. Ann Glob Health 2018;84:225-38.

16. Widiana DR, Wang YF, You SJ, Yang HH, Wang LC, Tsai JH, et al. Air pollution profiles and health risk assessment of ambient volatile organic compounds above a municipal wastewater treatment plant, Taiwan. Aerosol Air Qual Res 2019;19:375-82.

17. Lerner JEC, Sanchez EY, Sambeth JE, Porta AA. Characterization and health risk assessment of VOCs in occupational environments in Buenos Aires, Argentina Atmos Environ 2012;55:440-7.

18. Zhang ZJ, Yan XY, Gao FL, Thai P, Wang H, Chen D, et al. Emission and health risk assessment of volatile organic compounds in various processes of a petroleum refinery in the Pearl River Delta, China. Environ Pollut 2018, 238:452-61.

19. Lin CK, Hung HY, Christiani DC, Forastiere F, Lin RT. Lung cancer mortality of residents living near petrochemical industrial complexes: a meta-analysis. Environ Health-Glob 2017;16:101.

20. Alghamdi MA, Khoder M, Abdelmaksoud AS, Harrison RM, Hussein T, Lihavainen $\mathrm{H}$, et al. Seasonal and diurnal variations of BTEX and their potential for ozone formation in the urban background atmosphere of the coastal city Jeddah, Saudi Arabia. Air Qual Atmos Hlth 2014;7:467-80.

21. Domingo JL, Marquas M, Nadal M, Schuhmacher M. Health risks for the population living near petrochemical industrial complexes. 1. Cancer risks: a review of the scientific literature. Environ Res 2020;186:109495.

22. Durmusoglu E, Taspinar F, Karademir A. Health risk assessment of BTEX emissions in the landfill environment. J Hazard Mater 2010;176:870-7.

23. Gallego E, Roca FJ, Perales JF, Gadea E. Outdoor air 1,3-butadiene monitoring near a petrochemical industry (Tarragona region) and in several Catalan urban areas using active multi-sorbent bed tubes and analysis through TD-GC/MS. Sci Total Environ 2018:618:1440-8.

24. IARC. List of Classifications - IARC Monographs on the Identification of Carcinogenic Hazards to Humans. Lyon; 2019.

25. Divine BJ, Hartman CM. A cohort mortality study among workers at a 1,3 butadiene facility. Chem Biol Interact 2001;135:535-53.

26. Gun RT, Pratt N, Ryan P, Roder D. Update of mortality and cancer incidence in the Australian petroleum industry cohort. Occup Environ Med 2006;63: 476-81.
27. Ward E, Boffetta P, Andersen A, Colin D, Comba P, Deddens JA, et al. Update of the follow-up of mortality and cancer incidence among European workers employed in the vinyl chloride industry. Epidemiology. 2001:12:710-8.

28. Zheng JY, Yu YF, Mo ZW, Zhang Z, Wang XM, Yin SS, et al. Industrial sectorbased volatile organic compound (VOC) source profiles measured in manufacturing facilities in the Pearl River Delta, China. Sci Total Environ 2013;456:127-36.

29. Yuan B, Shao M, Lu SH, Wang B. Source profiles of volatile organic compounds associated with solvent use in Beijing, China. Atmos Environ 2010:44:1919-26.

30. Liu Y, Shao M, Fu LL, Lu SH, Zeng LM, Tang DG. Source profiles of volatile organic compounds (VOCs) measured in China: part I. Atmos Environ 2008; 42:6247-60

31. Beelen R, Raaschou-Nielsen O, Stafoggia M, Andersen ZJ, Weinmayr G, Hoffmann B, et al. Effects of long-term exposure to air pollution on naturalcause mortality: an analysis of 22 European cohorts within the multicentre ESCAPE project. Lancet. 2014;383:785-95.

32. Mo ZW, Shao M, Lu SH, Niu H, Zhou MY, Sun J. Characterization of nonmethane hydrocarbons and their sources in an industrialized coastal city, Yangtze River Delta, China. Sci Total Environ. 2017;593:641-53.

33. Zhao Y, Mao P, Zhou YD, Yang Y, Zhang J, Wang SK, et al. Improved provincial emission inventory and speciation profiles of anthropogenic nonmethane volatile organic compounds: a case study for Jiangsu, China. Atmos Chem Phys. 2017;17:7733-56.

34. Li GH, Wei W, Shao X, Nie L, Wang HL, Yan X, et al. A comprehensive classification method for VOC emission sources to tackle air pollution based on VOC species reactivity and emission amounts. J Environ Sci-China 2018; $67: 78-88$.

35. Wang HL, Qiao YZ, Chen CH, Lu J, Dai HX, Qiao LP, et al. Source profiles and chemical reactivity of volatile organic compounds from solvent use in Shanghai, China. Aerosol Air Qual Res 2014;14:301-10.

36. Tsai JH, Lin KH, Chen CY, Lai N, Ma SY, Chiang HL. Volatile organic compound constituents from an integrated iron and steel facility. J Hazard Mater 2008;157:569-78.

37. Cheng H, Sathiakumar N, Graff J, Matthews R, Delzell E. 1,3-butadiene and leukemia among synthetic rubber industry workers: exposure-response relationships. Chem Biol Interact 2007;166:15-24

38. Zheng H, Kong SF, Yan YY, Chen N, Yao LQ, Liu X, et al. Compositions, sources and health risks of ambient volatile organic compounds (VOCs) at a petrochemical industrial park along the Yangtze River. Sci Total Environ 2020;703:135505.

39. Loomis D, Guyton KZ, Grosse Y, El Ghissassi F, Bouvard V, Benbrahim-Tallaa L, et al. Carcinogenicity of benzene. Lancet Oncol 2017;18:1574-75.

40. Filley CM, Halliday W, Kleinschmidt-DeMasters BK. The effects of toluene on the central nervous system. J Neuropathol Exp Neurol 2004;63:1-12.

41. Kandyala R, Raghavendra SPC, Rajasekharan ST. Xylene: an overview of its health hazards and preventive measures. J Oral Maxill Pathol 2010;14:1.

42. Kirkeleit J, Riise T, Bratveit M, Moen BE. Increased risk of acute myelogenous leukemia and multiple myeloma in a historical cohort of upstream petroleum workers exposed to crude oil. Cancer Causes Control 2008:19:13-23.

43. Lin CK, Hsu YT, Christiani DC, Hung HY, Lin RT. Risks and burden of lung cancer incidence for residential petrochemical industrial complexes: a metaanalysis and application. Environ Int 2018;121:404-14.

44. TEPA. Taiwan Emission Data System Version 10.1. Taipei: Taiwan Environmental Protection Administration; 2020. https://teds.epa.gov.tw/ TEDS.aspx/ [in Chinese].

45. Dhital NB, Yang HH, Wang LC, Hsu YT, Zhang HY, Young LH, et al. VOCs emission characteristics in motorcycle exhaust with different emission control devices. Atmos Pollut Res 2019;10:1498-506.

46. Geng CM, Yang W, Sun XS, Wang X, Bai ZP, Zhang X. Emission factors, ozone and secondary organic aerosol formation potential of volatile organic compounds emitted from industrial biomass boilers. J Environ Sci-China 2019;83:64-72.

47. Zheng JY, Shao M, Che WW, Zhang $L$, Zhong $\sqcup$, Zhang YH, et al. Speciated VOC emission inventory and spatial patterns of ozone formation potential in the Pearl River Delta, China. Environ Sci Technol 2009;43:8580-6.

48. Tsai JH, Gu WT, Chung II, Chiang HL. Airborne air toxics characteristics and inhalation health risk assessment of a metropolitan industrial complex. Aerosol Air Qual Res 2019:19:2477-89. 
49. Tang JH, Chu KW, Chan LY, Chen YJ. Non-methane hydrocarbon emission profiles from printing and electronic industrial processes and its implications on the ambient atmosphere in the Pearl River Delta, South China. Atmos Pollut Res 2014;5:151-60.

50. Kiurski JS, Maric BB, Aksentijevic SM, Oros IB, Kecic VS. Occupational hazards in printing industry. Int J Environ Sci Te. 2016;13:955-72.

51. Zhao P, Cheng YH, Lin CC, Cheng YL. Effect of resin content and substrate on the emission of BTEX and carbonyls from low-VOC water-based wall paint. Environ Sci Pollut R 2016;23:3799-808.

52. Bailey MA, Costin CR. Unsaturated polyester resin compositions comprising metallic monomers. Alexandria: US Patent and Trademark Office; 2002.

53. Tsubaki H, Inokuchi S, Hirose I, Kosaka T. Double-sided pressure-sensitive adhesive tape for fixing decorative panel. Alexandria: US Patent and Trademark Office; 2011.

54. Chang CT, Lin KL. Assessment of the strategies for reducing VOCs emission from polyurea-formaldehyde resin synthetic fiber leather industry in Taiwan. Resour Conserv Recy 2006:46:321-34.

55. Wang BG, Feng ZC, Zhou Y, Liu HX. VOC components in the air caused by the local polyurethane synthetic leather industries in the Pearl River Delta region. China Environ Sci 2009;29:914-8.

56. Liu BS, Liang DN, Yang JM, Dai QL, Bi XH, Feng YC, et al. Characterization and source apportionment of volatile organic compounds based on 1-year of observational data in Tianjin, China. Environ Pollut 2016;218:757-69.

57. Ou JM, Zheng JY, Li RR, Huang XB, Zhong ZM, Zhong LJ, et al. Speciated OVOC and VOC emission inventories and their implications for reactivitybased ozone control strategy in the Pearl River Delta region, China. Sci Total Environ 2015;530:393-402.

58. Jaars $K$, Vestenius M, van Zyl PG, Beukes JP, Hellén H, Vakkari V, et al. Receptor modelling and risk assessment of volatile organic compounds measured at a regional background site in South Africa. Atmos Environ 2018;172:133-48.

59. Tong $\mathrm{R}, \mathrm{Ma}$ X, Zhang $\mathrm{Y}$, Shao G, Shi M. Source analysis and health riskassessment of ambient volatile organic compounds in automobile manufacturing processes. Hum Ecol Risk Assess Int J 2018:1-25.

60. Wallace HW, Sanchez NP, Flynn JH, Erickson MH, Lefer BL, Griffin RJ. Source apportionment of particulate matter and trace gases near a major refinery near the Houston Ship Channel. Atmos Environ 2018;173:16-29.

\section{Publisher's Note}

Springer Nature remains neutral with regard to jurisdictional claims in published maps and institutional affiliations.

Ready to submit your research? Choose BMC and benefit from:

- fast, convenient online submission

- thorough peer review by experienced researchers in your field

- rapid publication on acceptance

- support for research data, including large and complex data types

- gold Open Access which fosters wider collaboration and increased citations

- maximum visibility for your research: over $100 \mathrm{M}$ website views per year

At $\mathrm{BMC}$, research is always in progress.

Learn more biomedcentral.com/submissions 